\title{
CARBON SINK AND BIO-CHEMICAL POTENTIALITY OF TWO LEGUME TREE SPECIES
}

\author{
Saifuddin $\mathbf{M}^{1,2, *}$, Osman $\mathbf{N}^{2} \&$ Khandaker $\mathbf{M M}^{3}$ \\ ${ }^{\text {I}}$ Computer and Communication Engineering (CCE), Faculty of Science, International Islamic University Chittagong, \\ Kumira, Chittagong-4318, Bangladesh \\ ${ }^{2}$ Institute of Biological Sciences, Faculty of Science, University of Malaya, 50603 Kuala Lumpur, Malaysia \\ ${ }^{3}$ School of Agricultural Science and Biotechnology, Faculty of Bioresources and Food Industry, Universiti Sultan \\ Zainal Abidin, Besut Campus, 22200 Besut, Terengganu, Malaysia \\ *saifuddin.cu.um@gmail.com
}

Submitted January 2019; accepted February 2020

\begin{abstract}
Interest in the carbon sink and bio-chemical potentiality of plants has increased efforts to explore the opportunities for climate change mitigation, to meet the growing bioenergy demand. This study was conducted with the objective to quantify the carbon sink and bio-chemical potentiality of Leucaena leucocephala and Peltophorum pterocarpum. Outstanding physiological performance, measured as photosynthesis, chlorophyll fluorescence, leaf chlorophyll content and biomass production was observed to be the highest in L. leucocephala. Leucaena leucocephala was found to be active in photosynthesis at very high $\mathrm{CO}_{2}$ concentrations. Likewise, L. leucocephala had a higher lignocellulose composition than $P$. pterocarpum. Also, a higher alpha-cellulose and hemicellulose content was observed in thin roots than in coarse roots and stem bark, while stem bark and coarse roots had higher level of lignin content. Overall results revealed that L. leucocephala had a good carbon sink potentiality and appeared to be a promising feedstock for high-value of biochemicals. Thus, it can be planted for climate change mitigation to fulfill future bioenergy and biochemical demand.
\end{abstract}

Keywords: Carbon sink, photosynthesis, biomass, lignocellulose

\section{INTRODUCTION}

Over the past 150 years, the amount of carbon in the atmosphere has increased by $30 \%$ (Mann \& John 2006, Geerts \& Linacre 2002). Higher atmospheric carbon dioxide $\left(\mathrm{CO}_{2}\right)$ may influence the air temperature and precipitation patterns leading to intermittent warmer and drier environments (Geerts \& Linacre 2002). A well proposed method to reduce atmospheric $\mathrm{CO}_{2}$ is to enhance carbon fixation or sequestration in soils (Schwartz 2014). By capturing atmospheric $\mathrm{CO}_{2}$ through photosynthesis, plants synthesise large amounts of organic molecules especially carbohydrates that make up materials or woody biomass of plants (Ort et al. 2015). These organic molecules are converted into cell wall compositions via metabolism or a number of other pathways (Ort et al. 2015). The produced lignocellulosic components are deposited in the shoot and root. The ratio of cell-wall components varies greatly among plant species. It even varies from tissue to tissue and with the developmental stage of the plant. Cellulose, hemicellulose and lignin are the main components in cell wall (Rowell 2012). In plant biomass, about $40-50 \%$ is cellulose, $23-32 \%$ is hemicelluloses and $15-25 \%$ is lignin (Rowell 2012). Thus, plant biomass is a potential source of a wide range of bio-chemicals. Biomass or woody bio-chemicals can be converted into liquid biofuel through various chemical processing (Abdeshahian et al. 2010). Recently, plant biomass or lignocellulosic biomass has received considerable attention as a potential feedstock for bioenergy such as biofuel (Naik et al. 2010). Biofuel helps in reducing greenhouse gases, and the conversion of biomass into biofuels is technically feasible. Thus, growing potential plants may be a way to reduce atmospheric $\mathrm{CO}_{2}$, increase carbon storage in biomass and promote sustainable biofuels production (Luedeling et al. 2014, Schwartz 2014).

However, different types of plants have different photosynthetic efficiency, morphology and biomass production capacity, as plant 
physiological process varies based on species, ontogeny and the environment of the plants (Ludewig \& Ulf-Ingo 2013, Pooter et al. 2012). In addition, photosynthetic efficiency of plants is influenced by light intensity, temperature and concentration of $\mathrm{CO}_{2}$ in the atmosphere (Luedeling et al. 2014, Prior et al. 2011). Chlorophyll content and fluorescence of leaf can be used as signs to gauge the survival stage and condition of plants. Environmental stresses, e.g. extreme temperature, light and water availability, can reduce the ability of a plant to metabolise normally (Ashraf \& Harris 2013). Thus, leaf photosynthesis and chlorophyll fluorescence have been widely used in screening and identifying photo-chemically efficient plant species/genotypes for better carbon sequestration in climate change scenarios (Zhu et al. 2012, Noormets et al. 2010).

Therefore, selection of plant species by observing the potential physiological characteristics and yield of biochemicals is very important. Many legumes, especially woody trees, can play an important role in climate change mitigation as a source of renewable biochemicals (Anderson \& Don 2013, Jensen et al. 2012). The leguminous tree is a good choice as it has the ability to grow in low fertile soil. Amongst the legume woody trees, two natives (Leucaena leucocephala and Peltophorum pterocarpum), with potential to be prospective plants were chosen in this study. Leucaena leucocephala is one of the most productive fast growing, semi ever green, nitrogen fixing and tropical legume tree (Saifuddin \& Normaniza 2014). In Malaysia, L. leucocephala is used as a shade tree and wind protection for a variety of crops. Likewise, P. pterocarpum is a woody ornamental plant with huge root biomass (Saifuddin et al. 2015). This tree is usually found planted along roadsides, and in gardens and parks. It naurally grows along beaches and in mangrove forests, especially the inner margins of mangroves. In view of these aforementioned functions, carbon sink and bio-chemical potentiality of $L$. leucocephala and P. pterocarpum in tropical environment has not been well characterised. Therefore, the objective of this study was to identify the best potential species for mitigating atmospheric $\mathrm{CO}_{2}$ and examine its biomass productivity of naturally high lignocellulosic chemicals.

\section{MATERIALS AND METHODS}

\section{Plant materials and experimental setup}

Two native legume tree species, $L$. leucocephala and P. pterocarpum, were selected for this experiment. Seedlings at an average age of 15 days were grown in polyvinylchloride (PVC) pots $(30 \mathrm{~cm}$ in diameter and $70 \mathrm{~cm}$ in length) having $0.197 \mathrm{~m}^{3}$ soil with $3 \mathrm{~m}$ planting distance between plants. Based on the grain size distribution curve, the soil was described as sandy loam (Saifuddin \& Normaniza 2014). The seedlings were grown without fertilisation for eighteen months under prevailing conditions; relative humidity $(\mathrm{RH})$ (70-90\%), photosynthetically active radiation (PAR) (maximum $2200 \mu \mathrm{E} \mathrm{m}^{-2} \mathrm{~s}^{-1}$ ), temperature $\left(32-38{ }^{\circ} \mathrm{C}\right)$ and average monthly rainfall of 228 $\mathrm{mm} \mathrm{month}{ }^{-1}$ for the period of January 2011 to December 2012. The experimental site was located at Plant Physiology Garden, Institute of Biological Science, University of Malaya $\left(3^{\circ} 07^{\prime}\right.$ $\mathrm{N}$ and $101^{\circ} 39^{\prime} \mathrm{E}$ ). The plants were arranged in a complete randomised design (CRD) with four replications.

\section{Measurements of plant height and leaf chlorophyll content}

The plant height $(\mathrm{cm})$ was measured using a measuring tape. The chlorophyll content (SPAD or $\mathrm{Chl}$ in $\mu \mathrm{gcm}^{-2}$ ) was measured in five fully expanded leaves per plant, and replicated with four plants per species, using a portable chlorophyll meter. These measurements were taken at the $6^{\text {th }}$ and $18^{\text {th }}$ month of plant growth.

\section{Measurements of chlorophyll fluorescence and photosynthetic rate}

The chlorophyll fluorescence (arbitrary units) was measured in five fully expanded leaves per plant, and replicated with four plants per species, at the $18^{\text {th }}$ month of plant growth using a plant efficiency analyser. A clip was attached to one of the leaf and kept in the dark for 40-45 minutes for dark adaptation; the clip was then oriented with the shutter plate. When light was applied to the leaf, the fluorescence signal was counted for 3 seconds and the quantum yield or photosynthetic yield (temperature $=28{ }^{\circ} \mathrm{C}$ and time range $=10 \mu^{-3} \mathrm{sec}$ ) was measured. The maximal 
fluorescence $(\mathrm{Fm})$ and minimal fluorescence $\left(F_{0}\right)$ values were obtained. The yield of variable fluorescence $(F v)$ was calculated as $F m-F o$, and the calculation of chlorophyll fluorescence was determined according to the equation $\mathrm{Fv} / \mathrm{Fm}$ (Govindjee 2011). The photosynthetic rate was measured between 10:00 to 11:00 hours in five fully expanded leaves per plant, and replicated with four plants per species, using the portable photosynthesis system, at the $18^{\text {th }}$ month of plant growth.

\section{Carbon dioxide and light response curves}

The carbon dioxide response curves were deduced using the following sequence of $\mathrm{CO}_{2}$ concentrations: $0,30,60,120,300,600,1200$, 1500,1800 and $2100 \mathrm{ppm}$. The reference photosynthetically active radiation (PAR) value was fixed at $1000 \mu \mathrm{mol} \mathrm{m} \mathrm{m}^{-2} \mathrm{~s}^{-1}$. Stomatal conductance $\left(\mathrm{mmol} \mathrm{m} \mathrm{m}^{-2} \mathrm{~s}^{-1}\right)$ and transpiration rate $\left(\mathrm{mmol} \mathrm{m} \mathrm{m}^{-2} \mathrm{~s}^{-1}\right)$ were recorded concurrently with assimilation rate. These data were recorded for approximately 30-40 $\mathrm{min}$. For the light response curves, the assimilation rates were measured using the following sequence of light (PAR) levels: 0, 15, 30, 60, 120, 300, 600, 900, 1200,1500 and $2000 \mu \mathrm{mol} \mathrm{m}^{-2} \mathrm{~s}^{-1}$. The $\mathrm{CO}_{2}$ influx was adjusted to maintain an inside chamber concentration of $400 \mathrm{ppm}$.

\section{Plant biomass}

The shoot and root dry biomass (g) (oven-dried at $80^{\circ} \mathrm{C}$ for $72 \mathrm{~h}$ ) were determined using a balance, after eighteen months of plant growth. Four replications were used for this measurement.

\section{Root chemical analysis}

Root samples of plant species were ground into fine powder. The method applied to measure hemicellulose content ( $\%$ of biomass) was based on the procedure developed by Genet et al. (2010). Alpha-cellulose (\% of biomass) was determined by TAPPI 203 os-74 method. The acid-insoluble lignin content (\% of biomass) was determined in accordance with TAPPI 222 om-02 method (TAPPI 1998.)

\section{Statistical analysis}

Statistical analysis was carried out using SPSS software (version 16). The one way ANOVA was applied to evaluate the significant difference among means. A t-test was applied to assess the significant difference between means. Microsoft excel was used for regression analysis and graphical presentation.

\section{RESULTS}

\section{Physiological roles of studied species}

Results showed that there were differences in plant height and chlorophyll content between both species at both $6^{\text {th }}$ and $18^{\text {th }}$ month of plant growth. At the $18^{\text {th }}$ month of growth, plant height of L. leucocephala was higher by $88 \%$ than P. pterocarpum (Table 1). Likewise, the chlorophyll content of L. leucocephala was higher by $20 \%$ than $P$. pterocarpum. The chlorophyll content of leaf is important for photosynthesis, which allows plants to absorb energy from light and store the energy in the form of biomass (Rong-Hua et al.

Table 1 Plant height and leaf chlorophyll content of Leucaena leucocephala (LL) and Peltophorum pterocarpum (PP) over time

\begin{tabular}{lcccc}
\hline \multirow{2}{*}{ Plant characteristics } & Plant species & \multicolumn{3}{c}{ Plant age } \\
\cline { 3 - 5 } & & 6 months & 12 months & 18 months \\
\hline Plant height $(\mathrm{cm})$ & LL & $152.0 \pm 6 \mathrm{a}$ & $433.0 \pm 10 \mathrm{a}$ & $511.0 \pm 5 \mathrm{a}$ \\
& PP & $49.0 \pm 4 \mathrm{~b}$ & $198.0 \pm 6 \mathrm{~b}$ & $271.0 \pm 25 \mathrm{~b}$ \\
Leaf chlorophyll (SPAD) & LL & $61.5 \pm 0.9 \mathrm{a}$ & $60.8 \pm 1.1 \mathrm{a}$ & $61.1 \pm 0.7 \mathrm{a}$ \\
& PP & $50.0 \pm 1.2 \mathrm{~b}$ & $51.4 \pm 0.8 \mathrm{~b}$ & $50.8 \pm 0.5 \mathrm{~b}$ \\
\hline
\end{tabular}

Means ( \pm standard error) with different letters within the same column were significantly different $(\mathrm{p}<0.05, \mathrm{t}-\mathrm{test})$ 
2006, Ort et al. 2015). In addition, the results indicated that there was higher shoot and root biomass in L. leucocephala than P. pterocarpum (Table 2). The shoot and root biomass was positively correlated $(\mathrm{r}=0.89, \mathrm{p}<0.05)$, implying that a high shoot biomass of plant increased the root biomass (Figure 1). The high plant height may be attributed to the production of belowground biomass, which was in agreement with the findings of other researchers (Cunniff et al. 2015, Saifuddin \& Normaniza 2014). Fu et al. (2009) specified that canopy characteristics, plant biomass and plant growth were important factors for selecting revegetation species for soil conservation.

Chlorophyll fluorescence is an integral part of photosynthesis and provides information on plant metabolism and efficiency (Ashraf \& Harris 2013, Govindjee 2011). Table 3 shows that the chlorophyll fluorescence significantly varied between the two species, which indirectly indicated the health status of the individual plant. Leucaena leucocephala showed higher chlorophyll fluorescence than $P$. pterocarpum. This was due to the higher chlorophyll content in leaf and the capability of $L$. leucocephala to transport electrons through photosystem II (PS II) (Calatayud et al. 2002). Leucaena leucocephala showed excellent chlorophyll fluorescence (0.83), reflecting its outstanding photosynthesis capability, which resulted in high shoot and root biomass production (Calatayud et al. 2002). In contrast, the lower chlorophyll fluorescence of $P$. pterocarpum indicated that leaves were less efficient in utilising light energy, which led to less plant photosynthesis and biomass production. Therefore, the shoot and root biomass was lower in P. pterocarpum. Under ambient condition, photosynthetic rate showed significant variations between plants. The highest photosynthetic rate was observed in L. leucocephala whilst the lowest was obtained in P. pterocarpum. This result was possibly due to the reduced chlorophyll content and chlorophyll fluorescence in P. pterocarpum leaf. This could be due to species-specific variations in plant metabolism and biomass production (Jones et al. 2015). It was observed that photosynthetic rate and chlorophyll fluorescence were positively correlated $(\mathrm{r}=0.71, \mathrm{p}<0.05)$ (Figure 2$)$,

Table 2 Biomass of Leucaena leucocephala and Peltophorum pterocarpum at $18^{\text {th }}$ month of plant growth

\begin{tabular}{lcc}
\hline Species & Shoot biomass $(\mathrm{g})$ & Root biomass $(\mathrm{g})$ \\
\hline Leucaena leucocephala & $2327 \pm 207 \mathrm{a}$ & $994 \pm 14 \mathrm{a}$ \\
Peltophorum pterocarpum & $1744 \pm 94 \mathrm{~b}$ & $857 \pm 10 \mathrm{~b}$ \\
\hline
\end{tabular}

Means ( \pm standard error) with different letters within the same column were significantly different $(\mathrm{p}<0.05, \mathrm{t}$-test $)$

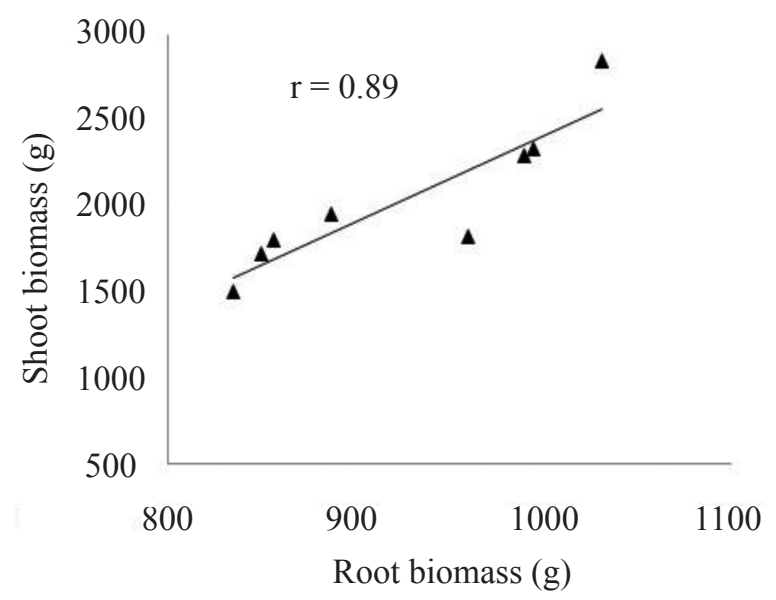

Figure 1 Relationship between shoot and root biomass of both species ( significantly different at $\mathrm{p}<0.05$ ) 
Table 3 Chlorophyll fluorescence and photosynthetic rate of Leucaena leucocephala and Peltophorum pterocarpum at $18^{\text {th }}$ month of plant growth

\begin{tabular}{lcc}
\hline Species & Chlorophyll fluorescence & Photosynthetic rate $\left(\mu \mathrm{mol} \mathrm{CO}_{2} \mathrm{~m}^{-2} \mathrm{~s}^{-1}\right)$ \\
\hline Leucaena leucocephala & $0.83 \pm 0.01 \mathrm{a}$ & $40 \pm 2 \mathrm{a}$ \\
Peltophorum pterocarpum & $0.75 \pm 0.01 \mathrm{~b}$ & $32 \pm 1.2 \mathrm{~b}$ \\
\hline
\end{tabular}

Means ( \pm standard error) with different letters within the same column were significantly different $(\mathrm{p}<0.05$, t-test $)$

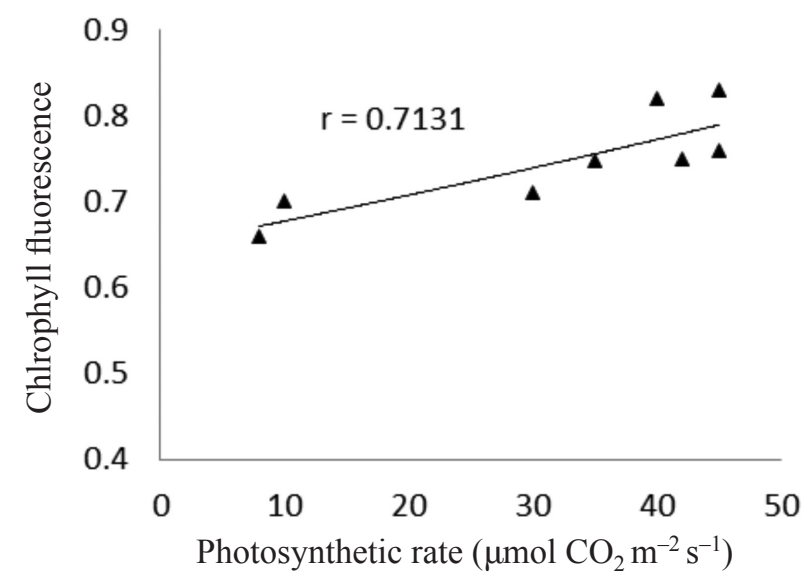

Figure 2 Relationship between chlorophyll fluorescence and photosynthetic rate of both species (significantly different at $\mathrm{p}<0.05$ )

implying that high chlorophyll fluorescence could help in improving the photosynthesis in the studied species. Thus, the chlorophyll fluorescence measurement could be used as an important parameter to estimate plant physiology for the selection of plants with high physiological performance.

\section{Carbon dioxide and light response curves}

The $\mathrm{CO}_{2}$ assimilation response of $L$. leucocephala and $P$. pterocarpum to different PAR was investigated up to a saturating intensity of 2000 umol m-2 $\mathrm{s}^{-1}$. The photosynthetic rate of both $L$. leucocephala and P. pterocarpum increased with increasing light intensity and reached saturation level at above $1000 \mu \mathrm{E} \mathrm{m}^{-2} \mathrm{~s}^{-1}$. Significant photosynthetic characteristics were observed at $600 \mu \mathrm{E} \mathrm{m}^{-2} \mathrm{~s}^{-1}$ as well. The maximum assimilation rate $\left(\mathrm{A}_{\max }\right)$ values were 64 and $33 \mu \mathrm{mol} \mathrm{CO}_{2} \mathrm{~m}^{-2} \mathrm{~s}^{-1}$ in L. leucocephala and P. pterocarpum, respectively (Figure 3). Both plants showed a similar trend in photosynthetic rates and were able to utilise high levels of light (greater than $1500 \mu \mathrm{mol} \mathrm{m} \mathrm{m}^{-2} \mathrm{~s}^{-1}$ ). However, when PAR was increased from ambient to triple ambient (400 to $1200 \mu \mathrm{mol} \mathrm{m} \mathrm{m}^{-2} \mathrm{~s}^{-1}$ ), the photosynthetic rates increased by $172 \%$ in L. leucocephala and $120 \%$ in P. pterocarpum.

The photosynthetic rates of both $L$. leucocephala and P. pterocarpum increased with increasing $\mathrm{CO}_{2}$ concentration and reached saturation level at above $1800 \mathrm{ppm}$. Significant photosynthetic characteristic was observed between the two species at $600 \mathrm{ppm}$. The maximum assimilation rate values were 124 and $80 \mu \mathrm{mol} \mathrm{CO} \mathrm{CO}^{-2} \mathrm{~s}^{-1}$ of L. leucocephala and P. pterocarpum, respectively (Figure 4). This indicated that L. leucocephala better remained photosynthetically active under high $\mathrm{CO}_{2}$ levels than $P$. pterocarpum.

\section{Chemical composition in plant biomass}

The basic structure of all plant biomass consists of cellulose, hemicelluloses, lignin and extractives. Their relative composition is shown in Table 4. The mean hemicelluloses content of L. leucocephala in stem bark, coarse root and thin root were $26.0,26.1$ and $29.2 \%$, respectively. Likewise, the mean hemicelluloses contents of $P$. pterocarpum in stem bark, coarse root and thin 


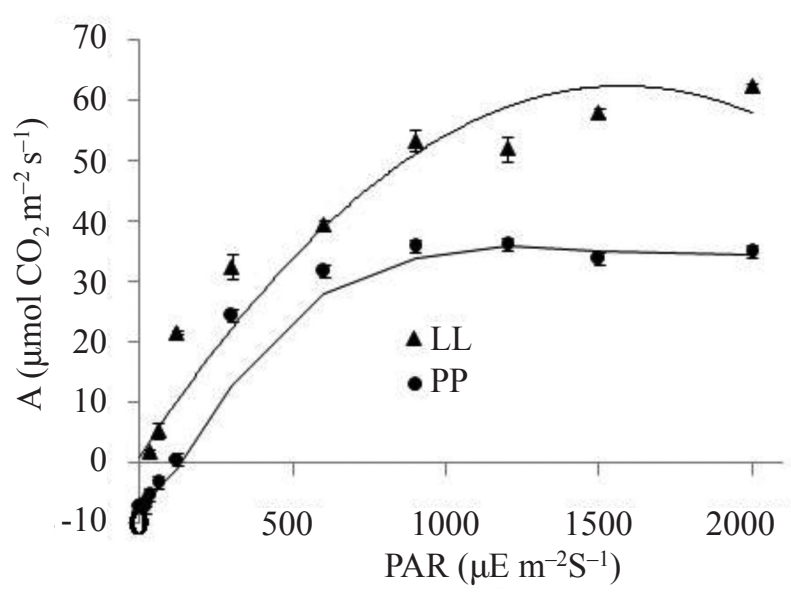

Figure 3 Light response curve of Leucaena leucocephala (LL) and Peltophorum pterocarpum (PP)

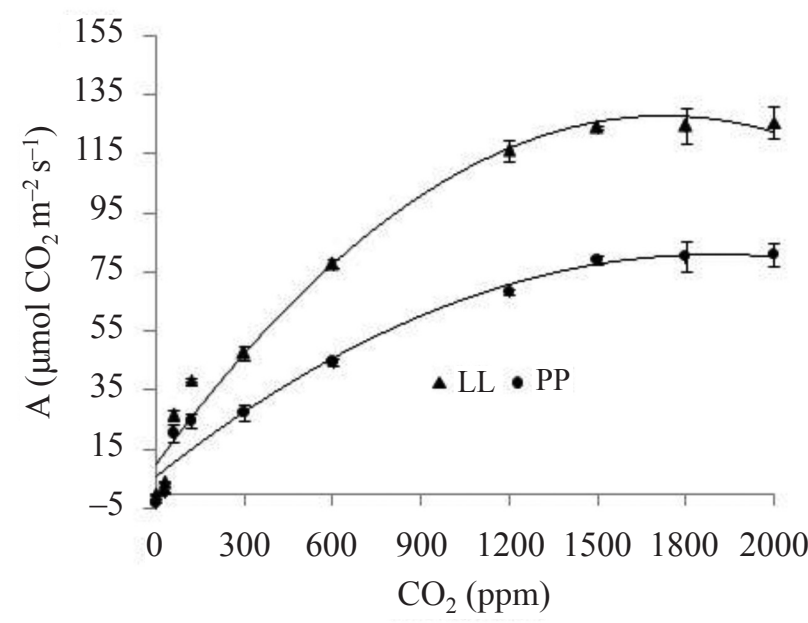

Figure 4 Carbon dioxide response curves of Leucaena leucocephala (LL) and Peltophorum pterocarpum (PP) at PAR of $1000 \mu \mathrm{E} \mathrm{m}^{-2} \mathrm{~s}^{-1}$

root were $25.7,25.4$ and $27.0 \%$, respectively. The hemicellulose content, of both species studied, was significantly higher in thin root than that of stem bark and coarse root. A significant difference in root alpha-cellulose and lignin content was observed between plant species, and coarse and thin roots. Mean alpha-cellulose content in the stem bark of L. leucocephala and P. pterocarpum were 44.8 and $31.5 \%$, respectively. Additionally, a similar pattern was observed in the lignin content where the stem bark of $L$. leucocephala had a higher value than P. pterocarpum. As observed in Table 4, lignin content in thin root of L. leucocephala was $17.6 \%$, which was higher than thin root of $P$. pterocarpum.

\section{DISCUSSION}

\section{Physiological characteristics of the plants}

In this study, L. leucocephala exhibited comparatively higher morphological traits than P. pterocarpum. A higher plant height and leaf chlorophyll content were observed in L. leucocephala than P. pterocarpum. A significant increase in biomass production was also observed in L. leucocephala, implying that high physiological performance could be involved in biomass production (Jones et al. 2015, Ugolini et al. 2015). Nandy et al. (2007) indicated that high physiological activity may be attributed to 
Table 4 Alpha-cellulose, hemicellulose and lignin content in plant biomass

\begin{tabular}{llccc}
\hline Species & Biomass types & $\begin{array}{c}\text { Alpha-cellulose } \\
(\%)\end{array}$ & $\begin{array}{c}\text { Hemicellulose } \\
(\%)\end{array}$ & $\begin{array}{c}\text { Lignin } \\
(\%)\end{array}$ \\
\hline $\begin{array}{l}\text { Leucaena } \\
\text { leucocephala }\end{array}$ & Stem bark $(28-34 \mathrm{~cm}$ in diameter $)$ & $44.8 \pm 0.3 \mathrm{~b}$ & $26.0 \pm 0.6 \mathrm{~b}$ & $23.9 \pm 0.02 \mathrm{a}$ \\
& Coarse roots $(20-30 \mathrm{~cm})$ & $44.5 \pm 0.4 \mathrm{~b}$ & $26.1 \pm 1.1 \mathrm{~b}$ & $23.4 \pm 0.02 \mathrm{a}$ \\
& Thin roots $(2-5 \mathrm{~cm})$ & $50.1 \pm 0.5 \mathrm{a}$ & $29.2 \pm 0.5 \mathrm{a}$ & $17.6 \pm 0.02 \mathrm{~d}$ \\
Peltophorum & Stem bark $(28-34 \mathrm{~cm}$ in diameter $)$ & $31.5 \pm 0.3 \mathrm{~d}$ & $25.7 \pm 0.4 \mathrm{~d}$ & $21.4 \pm 0.5 \mathrm{bc}$ \\
pterocarpum & Coarse roots $(20-30 \mathrm{~cm})$ & $31.3 \pm 0.2 \mathrm{~d}$ & $25.4 \pm 0.5 \mathrm{de}$ & $21.7 \pm 0.06 \mathrm{~b}$ \\
& Thin roots $(2-5 \mathrm{~cm})$ & $40.5 \pm 0.3 \mathrm{c}$ & $27.0 \pm 0.1 \mathrm{c}$ & $13.1 \pm 0.5 \mathrm{e}$ \\
\hline
\end{tabular}

Means ( \pm standard error) with different letters within the same column were significantly different $(\mathrm{p}<0.05, \mathrm{t}$-test $)$

the high chlorophyll content of leaves, which results in a greater competition for light and subsequently accelerates plant growth. It was reported that the physiological activities of plants varied significantly across species (Ugolini et al. 2015, Anderson \& Don 2013). Based on the correlation studies, root biomass and shoot biomass were positively correlated, indicating that a greater above ground biomass cover increases the below ground biomass (Normaniza et al. 2014).

Light energy, which is absorbed by PS II, can be converted to chemical energy to drive photosynthesis (Rong-hua et al. 2006). Chlorophyll fluorescence is the measurement of light that can be re-emitted after being absorbed by the chlorophyll molecules of leaves (Saifuddin \& Normaniza 2014). The chlorophyll fluorescence reflects whether the plant has suffered stresses or not, such as extreme temperature, light and water availability or lack of nutrients (Ashraf \& Harris 2013). Stress conditions can reduce the ability of a plant to metabolise normally, and consequently reduce the chlorophyll fluorescence value (Bibi et al. 2008). Therefore, the assessment of plant physiology by measuring the chlorophyll fluorescence is well documented (Calatayud et al. 2002). Moreover, the chlorophyll fluorescence also indicates an imbalance condition between the assimilation of light energy by the leaves and the use of light during photosynthesis (Rong-hua et al. 2006). In many plant species, an optimal chlorophyll fluorescence value is approximately 0.80 , and this value indicates healthy plants (Calatayud et al. 2002). Values of approximately 0.81-0.83 in L. leucocephala suggested that this species had better photosynthetic or light reaction ability than $P$. pterocarpum. The relatively higher chlorophyll fluorescence corresponded to the relatively higher photosynthetic rate. This could be due to the presence of strong correlation between chlorophyll fluorescence and photosynthetic rate. Thus, leaf chlorophyll content and chlorophyll fluorescence are indicators of plant physiological performance and the functions of plants to produce biomass. The high levels of biomass produced by a plant species determine the potential source of biochemical and bioenergy (Mckendry 2002).

\section{Carbon sink potentiality}

Plants that exhibit high photosynthetic components i.e., $\mathrm{A}_{\max }, \mathrm{A}_{400}$, light and $\mathrm{CO}_{2}$ saturation levels, are good carbon sink plants (Normaniza et al. 2014). In this study, L. leucocephala exhibited a higher photosynthetic rate than $P$. pterocarpum. In the simulated PAR levels, no photo-oxidation occurred in L. leucocephala, and it seemed to show a higher ability to capture light energy for photosynthesis than $P$. pterocarpum. Thus, the capacity to resist photo-oxidation indicated that L. leucocephala was a good potential carbon sink species. Besides $\mathrm{CO}_{2}$ response curves indicated the status of mesophyll activity which influenced the photosynthetic rate of plants. Changes in $\mathrm{CO}_{2}$ concentrations affected the photosynthesis of both species studied. However, L. leucocephala seemed to show higher ability to utilise high concentration of $\mathrm{CO}_{2}$ in order to enhance photosynthetic rate, as compared to $P$. pterocarpum. Similar results were observed in previous experiments conducted by Cernusak et al. (2011) on few legume tree species such as Albizia adinocephala \& Dalbergia retusa. Thongbai et al. (2010) found that an increased chlorophyll content in leaf significantly enhanced the photosynthetic rate under elevated $\mathrm{CO}_{2}$. The 
factors that may have had the strongest influence on the photosynthetic response of L. leucocephala includes the higher leaf chlorophyll content and chlorophyll fluorescence (Noormets et al. 2010, Zhu et al. 2012). Throughout the observation, under elevated $\mathrm{CO}_{2}$, L. leucocephala exhibited higher photosynthesis than P. pterocarpum, and it can grow well in carbon-rich environments. This is because L. leucocephala leaves possess high chlorophyll content and fluorescence value. Thus, warm conditions can enhance the productivity of L. leucocephala to absorb atmospheric $\mathrm{CO}_{2}$, as compared to $P$. pterocarpum. Thus, removal of excessive atmospheric $\mathrm{CO}_{2}$ through a potential plant like $L$. leucocephala would lead to mitigating global warming (Pinkard et al. 2010, Teng et al. 2006). The observation suggested that L. leucocephala is photosynthetically more efficient than P. pterocarpum. Thus, L. leucocephala is identified as a good carbon sink plant or future potential plant to survive in global warming stage.

\section{Biochemical content in plant biomass}

Leucaena leucocephala had significantly higher amount of alpha-cellulose, hemicellulose and lignin content than P. pterocarpum. Quantitative differences in chemical composition differed within the plant materials as well. Stem bark and coarse root were more abundant in lignin than thin or fine roots. Lignin provided the structural support and strength which is naturally required by stems and root crown (Labeeuw et al. 2015). On the other hand, fine roots were rich in hemicelluloses and alpha-cellulose. Young roots were rich in cellulosic compositions which were more resistant in tension. Genet et al. (2010) also reviewed several studies on root chemical variation in plants; lower diameter or thin roots usually having $10-20 \%$ higher cellulosic chemicals than coarse root. Wide variations of biochemical content in shoot and root have been reported in literature, and appeared to depend on species and site factors such as the local environment (Genet et al. 2010). However, in this study, both shoot and root biomass appeared to be an attractive sink for biochemicals. These chemicals can be used as a sustainable source of biofuel. As discussed earlier, plant based biomass is produced through photosynthesis (Ort et al. 2015). In photosynthesis, energy of sunlight is captured and stored as chemical forms in the tissues of living plants. Overall biomass production of plants depends on the physiological performance (i.e., photosynthetic apparatus and metabolism) which varies from plant to plant (Mckendry 2002). The amount of chemical compositions in biomass indicates the quality and potentiality of plant species as a source of bioenergy. Knowing accurately the chemical compositions in plant based biomass is important for enabling the commercial process of converting biomass into green biochemicals.

\section{CONGLUSION}

In this paper, we focused on plant physiology, biomass production and biochemicals of $L$. leucocephala and P. pterocarpum. Plant photosynthesis is the process by which chlorophyll containing leaves capture light energy and convert it into biochemicals. Leucaena leucocephala exhibited higher photosynthesis, chlorophyll fluorescence and leaf chlorophyll content than $P$. pterocarpum. It was found that L. leucocephala produced relatively higher biomass and demonstrated the ability to utilise high concentrations of $\mathrm{CO}_{2}$ and irradiance. The chemical composition of biomass varied between species and among the plant materials. Leucaena leucocephala showed higher alphacellulose, hemicelluloses and lignin content than P. pterocorpum. Among the plant biomass, higher lignin content was observed in coarse roots and stem bark than in thin roots, while hemicellulose and alpha-cellulose contents were observed to be higher in thin roots than in coarse roots and stem bark. Thus, this study suggested that $L$. leucocephala has added value as a potential plant for future high $\mathrm{CO}_{2}$ environment. Leucaena leucocephala may be resistant to photo-oxidation, which is an indicator for a good potential carbon sink plant. Finally, L. leucocephala can be used to fix $\mathrm{CO}_{2}$ from air and its biomass can be used for the production of valuable lignocellulosic compounds.

\section{ACKNOWLEDGMENTS}

This study was funded by the University of Malaya Research Grant (UMRG-PV052-2011A).

\section{REFERENCES}

Abdeshahian P, Dashti MG, Kalil MS \& Yusoff WMW. 2010. Production of biofuel using biomass as a sustainable 
biological resource. Biotechnology 9: 274-282. doi: 10.3923/biotech.2010.274.282.

Anderson LJ \& Don C. 2013. Gas exchange, growth, and defense responses of invasive Alliariapetiolata (Brassicaceae) and native Geumvernum (Rosaceae) to elevated atmospheric $\mathrm{CO}_{2}$ and warm spring temperatures. American Journal of Botany 100: 15441554. doi: 10.3732/ajb.1300014. Epub 2013 Jul 15.

Ashraf M \& Harris PJC. 2013. Photosynthesis under stressful environments: an overview. Photosynthetica 51: 163190. doi: 10.1007/s11099-013-0021-6.

Bibi AC, Oosterhuis DM \& Gonias ED. 2008. Photosynthesis, quantum yield of photosystem ii and membrane leakage as affected by high temperatures in cotton genotypes. The Journal of Cotton Science 12: 150-159.

Calatayud A, Ramirez JW, IGLESIAS DJ \& BARRENO E. 2002. Effects of ozone on photosynthetic $\mathrm{CO}_{2}$ exchange, chlorophyll a fluorescence and antioxidant systems in lettuce leaves. Physiologia Plantarum 116: 308-316. doi:10.1034/j.1399-3054.2002.1160305.x.

Cernusak LA, Winter K, Martínez C, Correa E, Aranda J, Garcia M \& Turner BL. 2011. Responses of legume versus nonlegume tropical tree seedlings to elevated $\mathrm{CO}_{2}$ concentration. Plant Physiology 157: 372-385. doi: doi.org/10.1104/pp.111.182436.

Cunniff J, Purdy SJ, Barraclough TJ et al. 2015. High yielding biomass genotypes of willow (Salix spp.) show differences in below ground biomass allocation. Biomass and Bioenergy 80: 114-127. doi: 10.1016/j. biombioe.2015.04.020.

Fu D, Duan C, Hou X, XIA T \& GaO K. 2009. Patterns and relationships of plant traits, community structural attributes, and eco-hydrological functions during a subtropical secondary succession in central Yunnan (southwest China). Archives of Biological Science Belgrade 61: 741-749. doi: 10.2298/ABS0904741F.

GeERTs B \& Linacre E. 2002. Changes in concentration of atmospheric carbon dioxide, other greenhouse gases, and aerosols. Carbon 3: 02.

Genet M, Li M, Luo T, Fourcaud T, Clément-Vidal A \& STOKEs A. 2010. Linking carbon supply to root cellwall chemistry and mechanics at high altitudes in Abiesgeorgei. Annals of Botany, 107: 311-320. doi: $10.1093 / \mathrm{aob} / \mathrm{mcq} 237$.

GovindJEE SA. 2011. On the relation between the Kautsky effect (Chlorophyll a fluorescence induction) and photosystem II: basic and applications of the OJIP fluorescence transient. Journal of Photochemistry and Photobiology B: Biology 104: 236-257. doi: 10.1016/j. jphotobiol.2010.12.010.

Jensen ES, Peoples MB, Boddey RM, Gresshoff PM, Hauggaard-Nielsen H, Alves BJ \& Morrison MJ. 2012. Legumes for mitigation of climate change and the provision of feedstock for biofuels and biorefineries-A review. Agronomy for Sustainable Development 32: 329-364. doi: 10.1007/s13593-0110056-7.

Jones MB, Finnan J \& Hodkinson TR. 2015. Morphological and physiological traits for higher biomass production in perennial rhizomatous grasses grown on marginal land. GCB Bioenergy 7: 375-385. doi: 10.1111/ gcbb.12203.
Labeeuw L, Martone PT, Boucher Y \& Case RJ. 2015. Ancient origin of the biosynthesis of lignin precursors. Biology Direct 10: 23. doi: 10.1186/s13062-015-0052-y.

LUDEWIG F \& Ulf-INGO F. 2013. Role of metabolite transporters in source-sink carbon allocation. Frontiers in Plant Science 4: 231. doi: 10.3389/fpls.2013.00231.

Luedeling E, Kindt R, Huth NI \& Koenig K. 2014. Agroforestry systems in a changing climate-challenges in projecting future performance. Current Opinion in Environmental Sustainability 6: 1-7. doi: 10.1016/j. cosust.2013.07.013.

MCKendRY P. (2002). Energy production from biomass (part 1): overview of biomass. Bioresource technology 83: 37-46. doi: 10.1016/S0960-8524(01)00118-3.

MANN KH \& John RNL. 2006. Dynamics of marine ecosystems: biological-physical interactions in the oceans. Oceanography 19: 157-159. doi: 10.1002/9781118687901.

NAIK SN, Goud VV, Rout PK \& DALAI AK. 2010. Production of first and second generation biofuels: a comprehensive review. Renewable and Sustainable Energy Reviews 14: 578-597. doi: 10.1016/j.rser.2009.10.003.

Nandy P, Das S, Ghose M \& SpoOner-Hart R. 2007. Effects of salinity on photosynthesis, leaf anatomy, ion accumulation and photosynthetic nitrogen use efficiency in five Indian mangroves. Wetlands Ecology and Management 15: 347-357. doi: 10.1007/s11273007-9036-8.

Noormets A, Kull O, Sôber A, Kubiske ME \& Karnosky DF. 2010. Elevated $\mathrm{CO}_{2}$ response of photosynthesis depends on ozone concentration in aspen. Environmental Pollution 158: 992-999. doi: 10.1016/j. envpol.2009.10.009.

Normaniza O, Saifuddin M \& Aimee H. 2014. Contribution of vegetation to alleviate slope's erosion and acidity. Pp 519-543 in Maria C. Hernez-Soriano (ed) Environmental Risk Assessment of Soil Contamination. IntechOpen Limited, London. doi: 10.5772/57228.

Ort DR, Merchant SS, Alric J, Barkan A, Blankenship RE, BOCK R \& MOORE TA. 2015. Redesigning photosynthesis to sustainably meet global food and bioenergy demand. Proceedings of the National Academy of Sciences 112: 8529-8536. doi:10.1073/ pnas.1424031112.

Pinkard EA, Beadle Cl, Mendham DS, Carter J \& Glen M. 2010. Determining photosynthetic responses of forest species to elevated $\left[\mathrm{CO}_{2}\right]$ : alternatives to FACE. Forest Ecology and Management 260: 1251-1261. doi: 10.1016/j.foreco.2010.07.018.

Poorter H, Niklas KJ, Reich PB, Oleksin J, Poot P \& Mommer L. 2012. Biomass allocation to leaves, stems and roots: meta-analyses of interspecific variation and environmental control. New Phytologist 193: 30-50. doi: 10.1111/j.1469-8137.2011.03952.x.

Prior SA, Runion GB, Marble SC, Rogers HH, Gilliam CH \& TORBERT HA. 2011. A review of elevated atmospheric $\mathrm{CO}_{2}$ effects on plant growth and water relations: implications for horticulture. Horticultural Science 46: 158-162. doi:10.21273/HORTSCI.46.2.158.

Rong-Hua LI, Pei-Guo Guo, Baum M, Grando S \& Ceccarelli S. 2006. Evaluation of chlorophyll content and fluorescence parameters as indicators of drought 
tolerance in barley. Agricultural Sciences in China 5: 751-757. doi:10.1016/S1671-2927(06)60120-X.

Rowell RM. 2012. Handbook of Wood Chemistry and Wood Composites. CRC Press LLC, Florida. doi: 10.1201/ b12487.

Saifuddin M, Osman N, Rahman MM \& Amru NB. 2015. Soil reinforcement capability of two legume species from plant morphological traits and mechanical properties. Current Science 108: 1340-1347. doi:10.18520/cs/ v108/i7/1340-1347.

SAifuddin M \& Normaniza O. 2014. Evaluation of hydromechanical properties and root architecture of plants for soil reinforcement. Current Science 107: 845-852. doi: $10.18520 / \mathrm{cs} / \mathrm{v} 107 / \mathrm{i} 5 / 845-852$.

Schwartz JD. 2014. Soil as Carbon Storehouse: New Weapon in Climate Fight. Yale Environment 360, New Haven.

Teng N, Wang J, Chen T, Wu X, Wang Y \& Lin J. 2006. Elevated $\mathrm{CO}_{2}$ induces physiological, biochemical and structural changes in leaves of Arabidopsis thaliana. New Phytologist 172: 92-103. doi: 10.1111/j.14698137.2006.01818.x.
Thongbai P, Kozai T \& Ohyama K. 2010. $\mathrm{CO}_{2}$ and air circulation effects on photosynthesis and transpiration of tomato seedlings. Scientia Horticulturae 126: 338-344. https:// doi.org/10.1016/j.scienta.2010.07.018.

TAPPI (Technical Association of Pulp and Paper Industry). 1998. Standard Methods for Acid-Insoluble Lignin in Wood and Pulp. T 222. Om-98. TAPPI, Atlanta.

Ugolini F, Bussotti F, Raschi A, Tognetti R \& Ennos AR. 2015. Physiological performance and biomass production of two ornamental shrub species under deficit irrigation. Trees 29: 407-422. doi: 10.1007/ s00468-014-1120-0.

Zhu Q, Jiang H, Peng C, Liu J, Fang X, Wei X, Liu S \& Zhou G. 2012. Effects of future climate change, $\mathrm{CO}_{2}$ enrichment, and vegetation structure variation on hydrological processes in China. Global and Planetary Change 80-81: 123-135. https://doi.org/10.1016/j. gloplacha.2011.10.010. 